\title{
The prevalence and determinants of anaemia in Jordan
}

Nour Abdo, ${ }^{1}$ Shahd Douglas, ${ }^{1}$ Anwar Batieha, ${ }^{1}$ Yousef Khader, ${ }^{1}$ Hashem Jaddou, ${ }^{1}$ Sohaib Al-Khatib, ${ }^{2}$ Mohammed El-Khatib, ${ }^{3}$ Hussain AbuZaid ${ }^{4}$ and Kamel Ajlouni ${ }^{3}$

${ }^{1}$ Department of Public Health, Faculty of Medicine, Jordan University of Science and Technology, Irbid, Jordan. ${ }^{2}$ Department of Pathology and Microbiology, Faculty of Medicine, Jordan University of Science and Technology, Irbid, Jordan. ${ }^{3}$ National Center for Diabetes, Endocrinology, and Genetics, Amman, Jordan. ${ }^{4}$ Royal Health Services, Jordanian Royal Medical Services, Amman, Jordan. (Correspondence to: Nour Abdo: nmabdo@just.edu.jo).

\begin{abstract}
Background: Anaemia is a global public health problem particularly in low- and middle-income countries and may be associated with serious health consequences. Limited studies, if any, have examined the prevalence and risk factors of anaemia in Jordan at the national level.

Aims: This study aimed to assess the prevalence of anaemia in Jordan for both sexes at the national level and to identify high-risk population subgroups.

Methods: A national population-based household sample was selected from the 12 governorates of Jordan in 2017. A total of 1125 males and 2797 females aged between 18 and 90 years were included. The prevalence of anaemia, overall and among subgroups of the population was estimated using $\mathrm{Hb}$ level as per WHO definition.

Results: Results showed prevalence of anaemia to be $4.9 \%$ in males, $19.3 \%$ in non-pregnant females, and $27.4 \%$ in pregnant females. The age standardized prevalence rates were $4.9 \%$ in males and $19.3 \%$ in females. The age standardized prevalence rates were $4.9 \%$ in males and $19.3 \%$ in females. Anaemia was predominantly mild (males: $81 \%$, non-pregnant females: $57 \%$, and pregnant females: 65.2\%). Sex, age, region, marital status, and education were significantly associated with anaemia. Iron deficiency anaemia (IDA) accounted for $68 \%$ of anaemic females and $38 \%$ of anaemic males.

Conclusions: The prevalence of anaemia in Jordan is lower than previously reported by WHO and the majority of anaemia was mild. Iron deficiency anaemia was the the most common type of anaemia, particularly in females. Flour fortification with iron and folic acid could have accounted for the decline of anaemia in Jordan.

Keywords: Anaemia, Jordan, iron deficiency, prevalence, national study

Citation: Abdo N; Douglas S; Batieha A; Khader Y; Jaddou H; Al-Khatib S; et al. The prevalence and determinants of anaemia in Jordan. East Mediterr Health J. 2019;25(5):341-349 https://doi.org/10.26719/emhj.18.047

Received: 16/01/18; accepted: 14/06/18

Copyright (C) World Health Organization (WHO) 2019. Some rights reserved. This work is available under the CC BY-NC-SA 3.o IGO license (https:// creativecommons.org/licenses/by-nc-sa/3.0/igo).
\end{abstract}

\section{Introduction}

The prevalence of anaemia has gradually declined in high-income countries, but it is still a major public health problem in many low- and middle-income countries. The World Health Organization (WHO) defines anaemia as a condition where the number of red blood cells (RBCs) or the oxygen-carrying capacity of $\mathrm{RBCs}$ is insufficient to meet the physiological needs. Anaemia affects 1.6 billion people worldwide, which corresponds to $24.8 \%$ of the total world population (1). Anaemia symptoms range from fatigue and weakness to reduced cognitive performance and even death. It can increase hospitalization and mortality rates among the elderly (2), and increase the maternal mortality rate $(3,4)$. Iron deficiency anaemia (IDA) is considered to be the most common nutritional deficiency worldwide. It can cause reduced work capacity in adults and affect motor and mental development in children and adolescents (5).

Women of reproductive age are a high-risk group for developing anaemia, due to menstruation, which is the principal risk factor for anaemia in women (6). Also, it is common during pregnancy to develop anaemia when the body might not be able to produce sufficient RBCs needed to make additional blood for the fetus (7). Approximately one-third of the older anaemic population have folate, iron, and/or vitamin B12 deficiency. Another third have chronic inflammation and/or renal insufficiency, and the remaining third have unexplained anaemia. It has been shown that anaemia is associated with poor survival rates in older adults (8).

There are a number of studies conducted on pregnant women and anaemia in urban and rural areas in Jordan $(9,10)$, but there are relatively few national level studies done to address this burning issue in the adult population. Anaemia is a serious problem that requires comprehensive understanding of its magnitude, types, and distribution in Jordan. The present study is an attempt to address this through assessment of the prevalence of the condition, its severity, causes, and distribution in different population subgroups.

\section{Methods}

\section{Sampling and data collection}

A national multipurpose population-based household sample was selected from the 12 governorates of Jordan. 
A multistage sampling technique was used to select the households. The first stage was a sampling of health centres since the population has access to an extensive network of health centres and the study is required to take place in a medical setting. A total of 17 health centres were included from the different governorates of Jordan. The second stage was a systematic sample of households from the catchment areas of the selected health centres. Two-member teams (one male and one female) moved door-to-door to select a systematic sample of households from the catchment area of the selected health centre. The teams invited household members $\geq 18$ years of age to participate in the study and to report next morning to the health centre after an overnight fast. In the health centre, each subject was interviewed by a trained interviewer using a structured questionnaire prepared specifically for the purposes of the study. Physical measurements included height, weight, blood pressure, and waist and hip circumferences were measured. Blood samples were drawn from each participant by trained laboratory technicians and finally analyzed. A total of 4056 subjects were finally included in the study from both sexes, 1193 males and 2863 females, aged between 18 and 90 years.

The study was multipurpose and collected extensive data on cardiovascular disease risk factors, vitamin B12, vitamin $\mathrm{D}$, and healthcare services. It was approved by the Ethical Committee for Research on Humans of the National Center for Diabetes, Endocrinology, and Genetics, Amman, Jordan. The study team obtained informed consent from all participants.

Sample size was estimated using the following formula:

\section{$\mathrm{n}=(\mathrm{za} / 2) 2 \mathrm{pq} / \Delta 2$}

Where $\mathrm{z}$ is the standard normal deviate (1.96 for a $95 \%$ confidence level), $\mathrm{p}$ is the expected prevalence for a disease, $\mathrm{q}$ is $1-\mathrm{p}$, and $\Delta$ is the margin of error. For the purpose of the present study, the corresponding margin of error is $1 \%$.

\section{Study variables and analyses}

All laboratory measurements were carried out at the Laboratories of the National Center for Diabetes, Endocrinology, and Genetics, Amman, Jordan. All laboratory work was carried out by the same team of laboratory technicians. As the study is multipurpose, a wide range of laboratory measurements were obtained including, fasting sugar, HbA1c, 25(OH)D, B12, etc. Haematological parameters, including haemoglobin, packed cell volume (PCV), mean corpuscular volume (MCV), mean corpuscular haemoglobin $(\mathrm{MCH})$ and mean corpuscular haemoglobin concentration $(\mathrm{MCHC})$, were measured using SYSMEX (XT-40oi) instrument (Sysmex Corporation,, Kobe, Japan). Biochemical parameters, serum iron, and total iron capacity were each measured using automated chemistry analyzer, COBAS 601, (Roche Diagnostics, Basel, Switzerland), while ferritin was measured by immunoassay using ADVIA CENTURA XP (Siemens Healthcare, Erlangen, Germany).
Haemoglobin $(\mathrm{Hb})$ cutpoints used in this study are summarized in Supplementary Table 1. MCV was classified as follows: microcytic anaemia ( $<80 \mathrm{fL} /$ red cell), normocytic anaemia (80-95 fL/red cell) and macrocytic (>95 fL/red cell). Normal range for $\mathrm{MCH}$ was $27-33 \mathrm{pg} /$ cell and were considered to be normochromic. Normal ferriten levels were between 30 to $400 \mu \mathrm{g} / \mathrm{L}$ in males and betweem 13 to $150 \mu \mathrm{g} / \mathrm{L}$ in females. Iron Defcicney (ID) was based on low ferriten levels. Education was categorized according to study years: Illiterate (o study years), primary education (1-10 study years), secondary education (10-12 study years), and higher education (above 12 study years). BMI was calculated by dividing weight in kilogrammes over height in metres squared and classified as: underweight $(<18)$, normal weight (18.5-24.9), overweight (25-29.9), and obese ( $\geq 30)$.

Data analyses were performed using SAS (Statistical Analysis System, version 9.2; SAS Institute, Cary, NC, USA). The data were initially checked for errors by performing range and logical checks. Detected errors were dealt with as appropriate. Prevalence of anaemia was analysed for each sex separately by age groups, region, marital status, education, occupation, and BMI. Differences were assessed for statistical significance by Chi-square test. To facilitate comparability, we used the WHO world population to obtain age standardized prevalence rates separately for males and females. Multivariable logistic regression analysis was performed to identify the most relevent determinants and risk factors of anaemia after controlling for potential confounders. Due to the small number of severe cases of anaemia, moderate and severe cases were combined to form a moderate-severe category in certain graphs.

\section{Results}

\section{Prevalence of anaemia and its determinants}

A total of 3922 individuals over 18 years of age were included in the study: 1125 (28.7\%) males, and 2797 (71.3\%) females. Several characteristics of the study population were summarized by sex, age groups, nationality, region, occupation, marital status, education, BMI, and pregnancy (in females only) (Table 1). The overall crude prevalence of anaemia in females was $20.5 \%$ (95\% CI, 19-22). The overall crude prevalence of anaemia in males was $5.2 \%$ (95\%, CI 3.9-6.5) (Table 1). The proportion of anaemic females was four times that of males $(P<0.001)$.

Anaemia was significantly associated with age in both sexes $(P<0.001)$. Figure 1 shows the prevalence of anaemia and moderate-severe anaemia in different age categories for each sex. Anaemia and moderate-severe anaemia has an increasing trend with age in males, with those aged over 70 years having the highest prevalence of anaemia (25\%) and moderate-severe anaemia (4.3\%) (Figure 1; Table 1). However, middle-aged (40-49 years) females had the highest prevalence of anaemia (28\%) and moderate-severe anaemia (13.1\%) (Figure 1; Table 1). The age-adjusted prevalence of anaemia was 19.3 (95\% CI, 


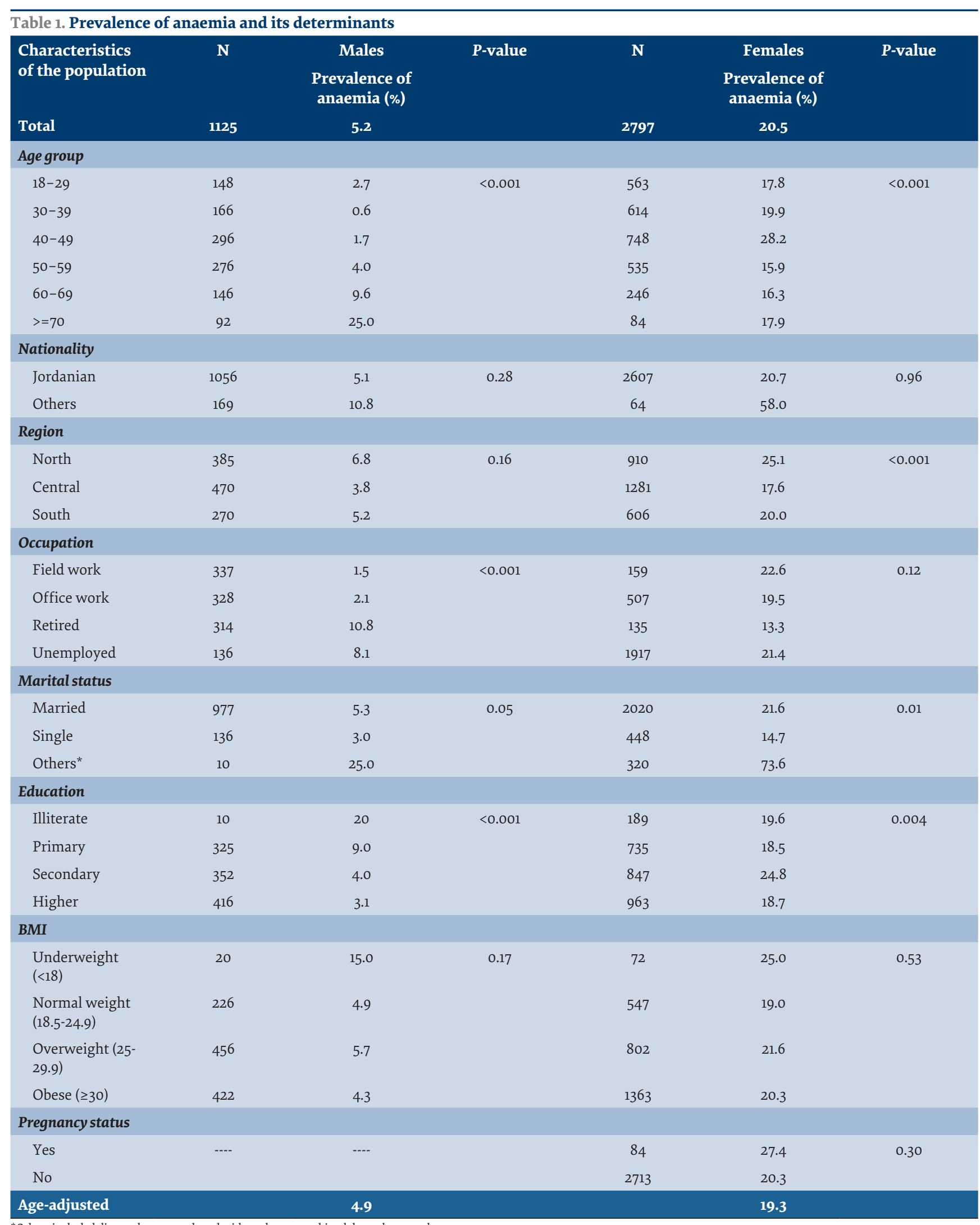

*Others included divorced, separated, and widowed were combined due to low numbers. 
Figure 1. Prevalence of anaemia and moderate-severe anaemia by age groups.

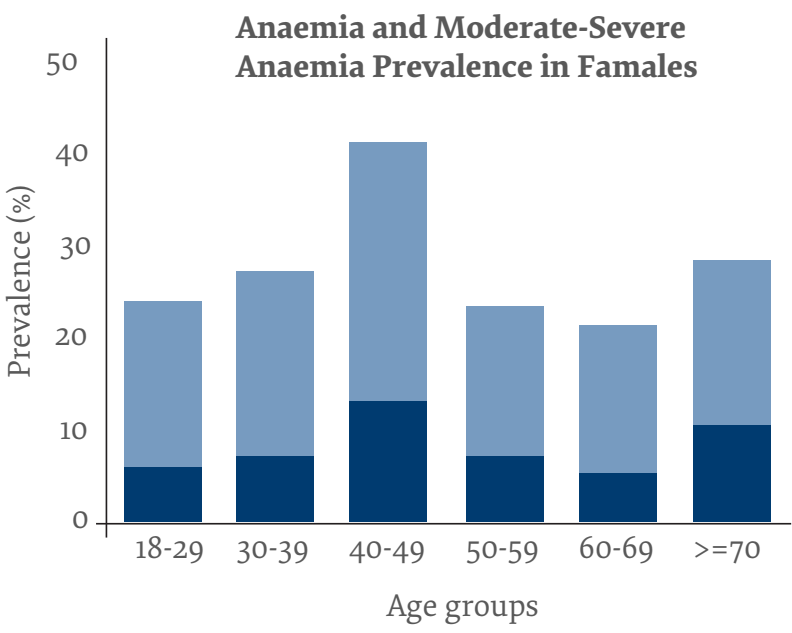

Moderate-Severe Anaemia - Anaemia

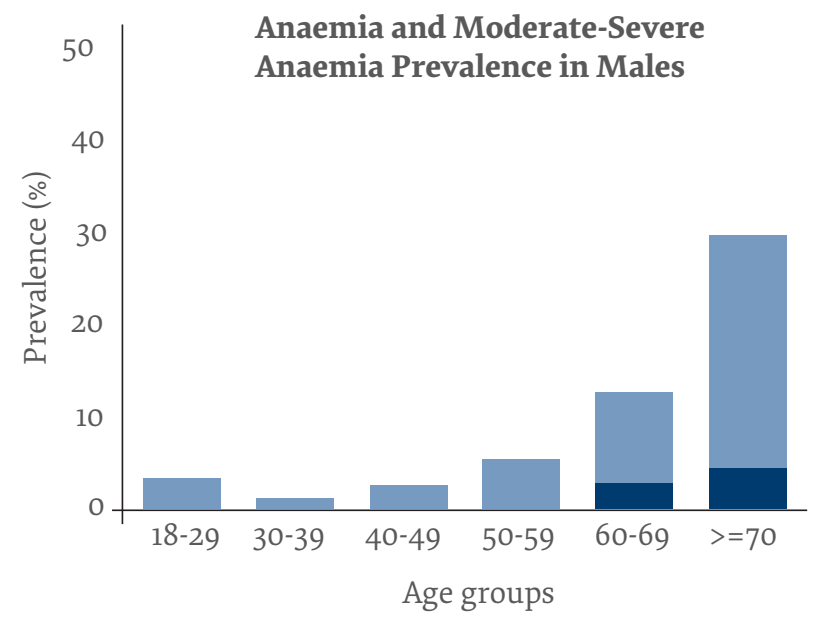

Moderate-Severe Anaemia — Anaemia

$17.8-20.8)$ in females and 4.9 (95\% CI, 3.4-5.8) in males, using the WHO standard population.

The prevalence of anaemia in females was significantly higher in northern Jordan, among subjects with secondary education, and in divorced, separated, or widowed females (Table 1). The prevalence of anaemia in males was significantly higher among working, lower educated, and divorced, separated, or widowed men (Table 1). Nationality, BMI, and pregnancy were not significantly associated with anaemia (Table 1).

\section{Stepwise multivariable logistic regression analysis}

Using logistic regression, the overall adjusted odds ratio of anaemia in females versus males was 5.3 (95\% CI, 3.9-7.1) after adjusting for education, marital status, region, and age (data not shown in tables). Multivariable logistic regression analysis was also performed for each sex separately. Table 2 shows the adjusted odds ratios for each variable and their $95 \%$ confidence intervals. Age and region were the only risk factors for anaemia in males.
Table 2. Adjusted odds ratios for significant variables using stepwise multivariate logistic regression

\begin{tabular}{|c|c|}
\hline $\begin{array}{l}\begin{array}{l}\text { Significant risk factors for } \\
\text { each sex }\end{array} \\
\text { Males }\end{array}$ & Odds Ratio (95\% CI) \\
\hline \multicolumn{2}{|l|}{ Age } \\
\hline $18-29$ & $0.08(0.03-0.25)$ \\
\hline $30-39$ & $0.02(0.00-0.12)$ \\
\hline $40-49$ & $0.05(0.02-0.13)$ \\
\hline $50-59$ & $0.11(0.05-0.25)$ \\
\hline $60-69$ & $0.28(0.13-0.60)$ \\
\hline$>=70$ & 1 \\
\hline \multicolumn{2}{|l|}{ Region $^{*}$} \\
\hline Northern & $1.43(0.71-2.90)$ \\
\hline Central & $0.56(0.26-1.21)$ \\
\hline Southern & 1 \\
\hline \multicolumn{2}{|l|}{ Females } \\
\hline \multicolumn{2}{|l|}{ Age } \\
\hline $18-29$ & $1.40(0.70-2.79)$ \\
\hline $30-39$ & $1.30(0.67-2.54)$ \\
\hline $40-49$ & $2.05(1.07-3.93)$ \\
\hline $50-59$ & $0.94(0.49-1.80)$ \\
\hline $60-69$ & $0.87(0.44-1.73)$ \\
\hline$>=70$ & 1 \\
\hline \multicolumn{2}{|l|}{ Region* } \\
\hline Northern & $1.36(1.05-1.77)$ \\
\hline Central & $0.87(0.67-1.13)$ \\
\hline Southern & 1 \\
\hline \multicolumn{2}{|l|}{ Marital status } \\
\hline Married & $1.60(1.15-2.22)$ \\
\hline Other* & $2.05(1.32-3.18)$ \\
\hline Single & 1 \\
\hline \multicolumn{2}{|l|}{ Education } \\
\hline Illiterate & $0.86\left(0.55^{-1.35)}\right.$ \\
\hline Primary & $0.70(0.54-0.90)$ \\
\hline Higher & $0.67(0.54-0.85)$ \\
\hline Secondary & 1 \\
\hline
\end{tabular}

In females, region, marital status, age, and education were found to be significantly associated with anaemia. The odds of having anaemia were significantly higher in males aged over 70 years. The odds of having anaemia in females were significantly higher among those that have low levels of education, not single, aged 40-49 years, and living in northern Jordan.

\section{Severity and type of anaemia in the Jor- danian population}

The prevalence of anaemia classified by its severity in both sexes according to the WHO classification is sum- 
Figure 2. Prevalence of anaemia and moderate-severe anaemia by age groups.
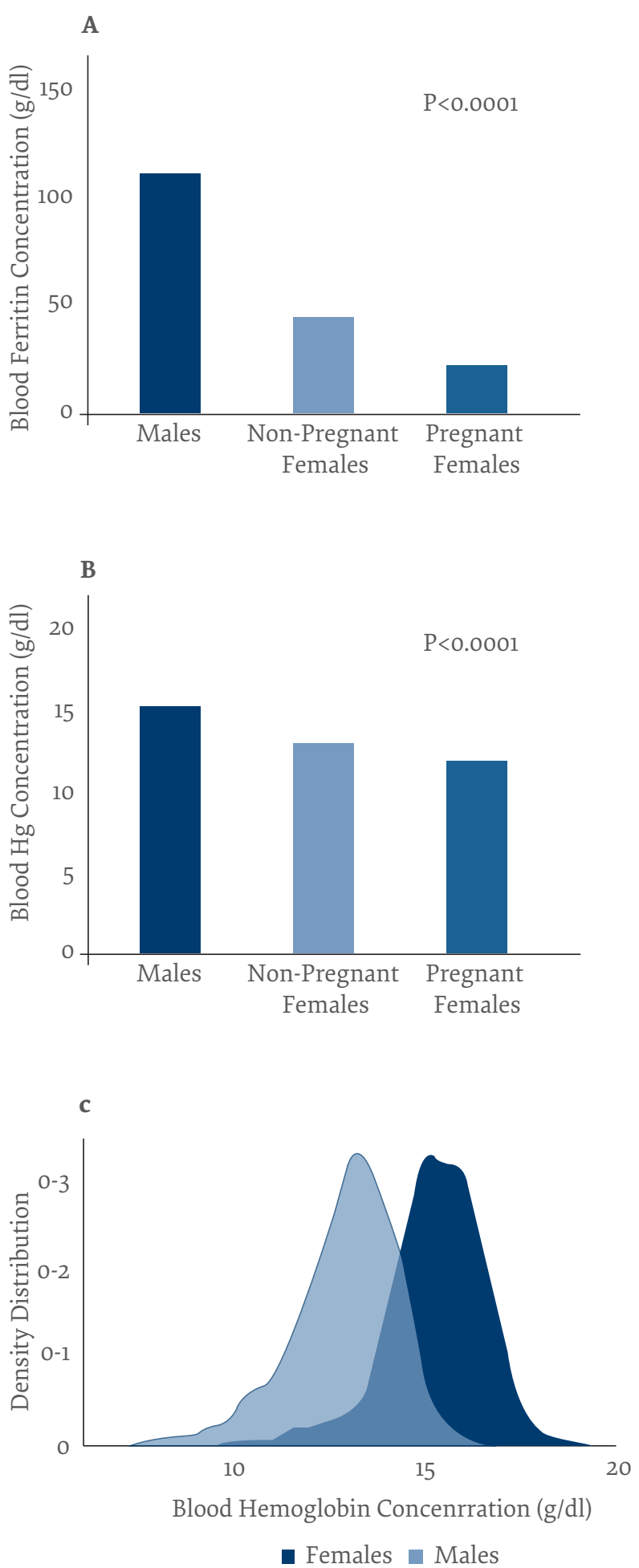

marized in Table 3. The proportion of moderate-severe anaemia in non-pregnant females (43\%) was almost twice that in males (19\%). Anaemia was predominantly mild at $81 \%, 57 \%$, and $65 \%$ in males, non-pregnant females, and pregnant females, respectively (Table 3 ).

The most common type of anaemia observed in males and females was microcytic hypochromic anaemia

\begin{tabular}{|c|c|c|c|}
\hline $\begin{array}{l}\text { Severity of } \\
\text { anaemia }\end{array}$ & $\begin{array}{c}\text { Males } \\
\mathbf{n}(\%)\end{array}$ & $\begin{array}{c}\text { Non- } \\
\text { pregnant } \\
\text { females } \\
\mathbf{n}(\%)\end{array}$ & $\begin{array}{c}\text { Pregnant } \\
\text { females } \\
\mathbf{n}(\%)\end{array}$ \\
\hline Mild anaemia* & $15(65.2)$ & $314(57.0)$ & $47(81.0)$ \\
\hline $\begin{array}{l}\text { Moderate } \\
\text { anaemia* }\end{array}$ & $8(34.8)$ & $223(40.5)$ & $11(19.0)$ \\
\hline Severe anaemia* & $\mathrm{o}(\mathrm{o})$ & $14(2.5)$ & $\mathrm{O}(\mathrm{o})$ \\
\hline
\end{tabular}

*According to WHO classifications, for males, non-anaemia: $\geq 13$ g/dl, mild anaemia: 11-12.9 g/dl, moderate anaemia: 8-10.9 g/dl and severe anaemia <8 g/dl. For non-pregnant females, non-anaemia: $\geq 12$ g/dl, mild anaemia: 11-11.9 g/dl, moderate anaemia: 8-10.9 g/dl, severe anaemia < 8 g/dl. For pregnant females, non-anaemia: $\geq 11$ g/dl, mild anaemia: 10-10.9 g/dl, moderate anaemia: 7-9.9 g/dl, severe anaemia $<7 \mathrm{~g} / \mathrm{dl}$.

\section{Supplemental Figure 1. Haemoglobin vs ferritin in low ferritin individuals by sex}
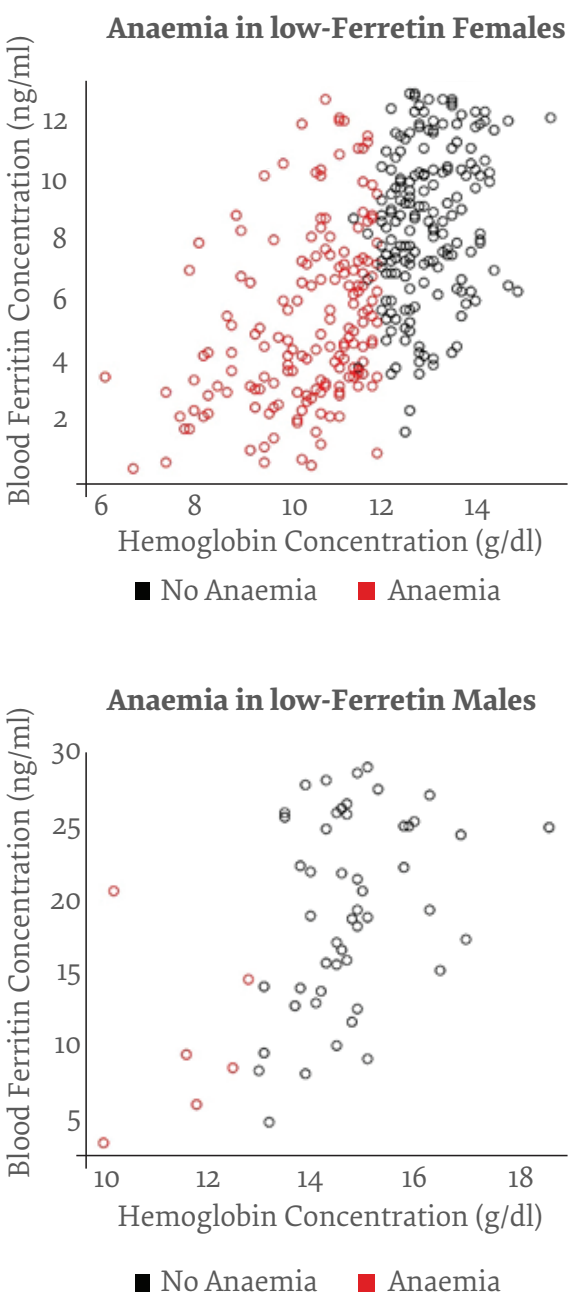

accounting respectively for $29.3 \%$ and $33.1 \%$, followed by normocytic normochromic anaemia at $24.1 \%$ in males and normocytic hypochromic anaemia at $30.8 \%$ in females (data not shown in tables). Slightly less than one third of the female population $(28.7 \%)$ had iron deficiency compared to $11.1 \%$ of males (data not shown in table). IDA accounted for $68.2 \%$ of anaemic females and $38.6 \%$ in anaemic males (data not shown in table). Average ferritin 


\begin{tabular}{|c|c|c|c|c|}
\hline \multicolumn{5}{|c|}{$\begin{array}{l}\text { Supplemental Table 1: Haemoglobin levels }(\mathrm{g} / \mathrm{dL}) \text { to diagnose } \\
\text { anaemia and its severity used in the study }\end{array}$} \\
\hline \multirow[t]{2}{*}{ Population } & \multirow{2}{*}{$\begin{array}{l}\text { Non- } \\
\text { Anaemia }\end{array}$} & \multicolumn{3}{|c|}{ Anaemia } \\
\hline & & Mild & Moderate & Severe \\
\hline $\begin{array}{l}\text { Non- } \\
\text { Pregnant } \\
\text { Females }\end{array}$ & $>12$ & $11-11.9$ & $8-10.9$ & $<8$ \\
\hline $\begin{array}{l}\text { Pregnant } \\
\text { Females }\end{array}$ & $>11$ & $10-10.9$ & $7-10.9$ & $<7$ \\
\hline Males & $>13$ & $11-12.9$ & $8-10.9$ & $<8$ \\
\hline
\end{tabular}

levels and standard errors are shown in Figure 2 panel $\mathrm{C}$ for males, females, and pregnant females.

Mean Hb levels in females (12.9 g/dL, 95\% CI, 12.9-13.0) were lower than that in males (15.3 g/dL, 95\% CI, 15.2-15.4) (Figure 2A). As expected, the distribution of haemoglobin for females was lower than that in males (Figure 2A). Haemoglobin levels were significantly different between males, non-pregnant females, and pregnant females. Means and standard errors for haemoglobin are shown for males, non-pregnant females, and pregnant females in Figure 2B.

\section{Discussion}

The present study is the first national study of anaemia incorporating both sexes in Jordan. We aimed to study a large representative sample of the population from all governorates. However, as expected, females were grossly overrepresented in our sample. The main reason behind that is the much higher rate of female unemployment exceeding $70 \%$ as compared to $12 \%$ in males, which makes women more available for participation.

A main finding of our study is the low rate of anaemia in males (4.9\%) and females (19.7\%). Compared to previous WHO findings in their 2006 report (11), Jordan has witnessed a substantial decline in anaemia in females, while the WHO report provides no data about males, which was based on data collected in 2002 . Anaemia decreased in non-pregnant females from $29 \%$ in 2002 to $20 \%$, in 2017 , and in pregnant females from $39 \%$ to $27 \%$. This can be attributed to the flour fortification programme with iron and folic, acid indicating that the programme is proving successful. The majority of remaining anaemic cases have mild anaemia.

In non-pregnant females, only 3 out of 21 countries in the Eastern Mediterranean Region (EMR), namely Pakistan, Saudi Arabia, and Somalia, have a prevalence of more than $40 \%$ (12). The remaining 18 countries, including Jordan, showed anaemia to be of moderate public health significance (20 to $40 \%$ prevalence) (12). The $2011 \mathrm{WHO}$ estimates ranked Jordan as the 13th highest country in the prevalence of anaemia among non-pregnant females in EMR (12). Kuwait had the lowest prevalence of $22 \%$ and Pakistan had the highest prevalence of 51\% (12). Our 2017 study shows that the age-adjusted prevalence of anaemia among females is even less than that previously reported from Kuwait.

Our study showed that the proportion of anaemic females was four times that of males. Being a female at the childbearing age is considered a risk factor for developing anaemia. Results of this study are consistent with most studies in the literature. Le et al. (2016) suggested that women of reproductive age had a high prevalence of anaemia (13), while a study conducted in Saudi Arabia indicated that the prevalence of anaemia in adolescent girls was higher than that in adolescent males (14). Ismail et al. (2016) stated that the prevalence of anaemia in females was almost double that in males in a study conducted in Kerala, India (15).

Anaemia and moderate-severe anaemia prevalence has an increasing trend with age in males. Males aged over 70 years had the highest prevalence of anaemia and moderate-severe anaemia, which agrees with the results of most studies in the literature $(8,16)$. The prevalence of anaemia increases with age particularly after 50 years of age (8). Similarly, Guralnik et al. (2004) found that anaemia prevalence rose rapidly after 50 years of age, and to a rate greater than $20 \%$ at age 85 years and older (16). In a study conducted in India, males above 30 years had significantly more chance of anaemia than males below 30 years (17). In Rural Uganda, a study stated that the prevalence of anaemia was higher for males than females and increased rapidly with age in males, to almost double between 50 and 65 years (18). On the other hand, middleaged (40 to 49 years) females had the highest prevalence of anaemia (28\%) and moderate-severe anemia (13.1\%), which concurs with the results in most studies. Women of reproductive age were found to be at high risk of developing anaemia, due to menstruation (19). In men, rates of anaemia increased monotonically with age, but for women increased bimodally with peaks in age group 40-49 years and $80-85$ years (20).

Several studies revealed that there is a direct association between education and the prevalence of anaemia. Factors such as socio-economic status and level of education were found to be significantly associated with the prevalence of anaemia among women (21). Moreover, among school-aged children, children with less educated mothers were more likely to develop anaemia and iron deficiency than were those with more educated mothers, since they consume more iron and protein from animal sources than do children of less educated mothers (22). Zaytoun et al. (2016) found that there was a significant association between anaemia and social status and educational level (20). In India, higher prevalence of anaemia was found in people with below senior secondary education than those with above senior secondary education (17).

The northern region of Jordan had the highest prevalence and odds ratio of anaemia. This is due to a noticeable high prevalence of anaemia, in both sexes, from a particular health centre in Shouneh Al-Shamalyia (Shouneh). The increased prevalence in this particular region could be related to the low socio-economic status 
and low altitude that is below sea level. Generally, haemoglobin levels are usually affected by high altitude. Interestingly, a 2012 study in Jordan showed that Hb levels were significantly lower for people living below sea level (in Shouneh Al-Shamalyia) when compared with people living above sea level in healthy adults (23). Furthermore, the lower socioeconomic and rural nature of Shouneh might also contribute to the poor nutritional status. Studies have showed that individuals living in rural areas were at a more than two fold increased risk of developing anaemia than those in urban areas $(15,20)$. Further studies should be conducted to confirm the suggested reasons for this high prevalence in the northern region.

The most common type of anaemia observed in our study was microcytic hypochromic anaemia which predominantly represents IDA. Anaemia in females was predominantly caused by iron deficiency where two thirds of anaemic females had IDA, while around $40 \%$ of anaemic males have IDA. Iron supplementation might increase $\mathrm{Hb}$ blood levels and greatly reduce the prevalence of anaemia in Jordan. Anaemia is a complex medical condition that might stem from multiple factors. Relying on same $\mathrm{Hb}$ cutoff points to define anaemia and its severity levels for all might not be completely accurate $(1,24)$. For example, smokers need different cutoff points or adjustments for anaemia evaluation than nonsmokers (24), which was not carried out in the present study.

\section{Conclusion}

In conclusion, anaemia in Jordan is currently a mild public health problem. The prevalence of anaemia has declined from previous reported levels. Most anaemic cases were mild in severity and caused by IDA as expected. It seems that the national flour fortification programme is beneficial.

Funding: This research was supported by the National Center for Diabetes, Endocrinology, and Genetics, and the Scientific Research Fund of the Ministry of Higher Education. Both provided financial support for the study.

Competing interests: None declared.

\section{Prévalence et déterminants de l'anémie en Jordanie}

Contexte : L'anémie est un problème de santé publique mondial, en particulier dans les pays à revenu faible et intermédiaire, qui peut être associé à de graves conséquences pour la santé. Des études limitées ont examiné la prévalence et les facteurs de risque de l'anémie en Jordanie au niveau national.

Objectifs : La présente étude visait à évaluer la prévalence de l'anémie au niveau national en Jordanie pour les deux sexes et à identifier les sous-groupes de population à haut risque.

Méthodes : Un échantillon national de ménages représentatif de la population a été sélectionné dans les 12 gouvernorats de Jordanie en 2017. Au total, 1125 hommes et 2797 femmes âgés de 18 à 90 ans ont été inclus. La prévalence de l'anémie, dans l'ensemble et parmi les sous-groupes de population, a été estimée en utilisant le taux d'hémoglobine selon la définition de l'OMS.

Résultats : Les résultats ont montré que la prévalence de l'anémie était de 4,9\% chez les hommes, de 19,3\% chez les femmes non enceintes et de $27,4 \%$ chez les femmes enceintes. Les taux de prévalence standardisée selon l'âge s'élevaient à $4,9 \%$ chez l'homme et 19,3\% chez la femme. L'anémie était principalement bénigne (hommes : $81 \%$, femmes non enceintes : $57 \%$, et femmes enceintes : $65,2 \%$ ). Le sexe, l'âge, la région, la situation de famille et le niveau de scolarité étaient significativement associés à l'anémie. L'anémie ferriprive touchait $68 \%$ des femmes anémiques et $38 \%$ des hommes anémiques.

Conclusions : La prévalence de l'anémie en Jordanie est inférieure à celle précédemment signalée par l'OMS et la majorité des cas d'anémie étaient de forme légère. L'anémie ferriprive était le type d'anémie le plus fréquent, en particulier chez les femmes. L'enrichissement de la farine en fer et en acide folique pourrait expliquer la diminution de l'anémie en Jordanie.

$$
\begin{aligned}
& \text { معدل انتشار فقر الدم والعو امل المحددة له في الأردن } \\
& \text { نور عبده، شهد دوجلاس، أنور بطيحة، يوسف خضر، هاشم جدوع، صهيب الخطيب، محمد الخطيب، حسين أبو زيد، كامل عجلوني } \\
& \text { الخالاصة }
\end{aligned}
$$

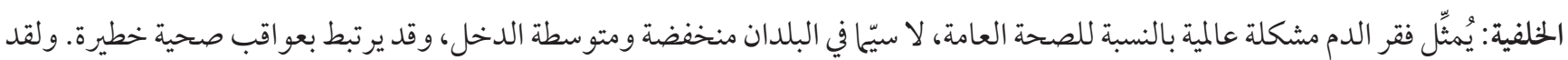

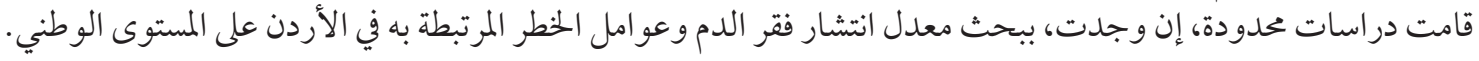

$$
\begin{aligned}
& \text { الأهداف: هدفت هذه الدراسة إلى تقييم معدل انتشار فقر الدم في الأردن بين الجنسين على المستوى الوطني، وتحديد الفئات السكانية الفرعية }
\end{aligned}
$$

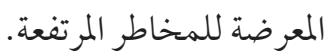

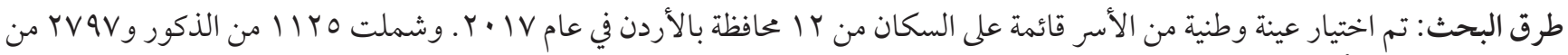

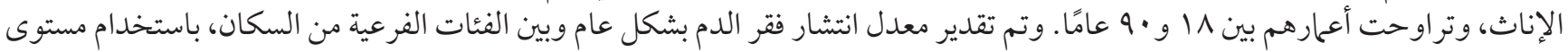

$$
\begin{aligned}
& \text { الهيمو جلوبين حسب تعريف منظمة الصحة العالمية. }
\end{aligned}
$$




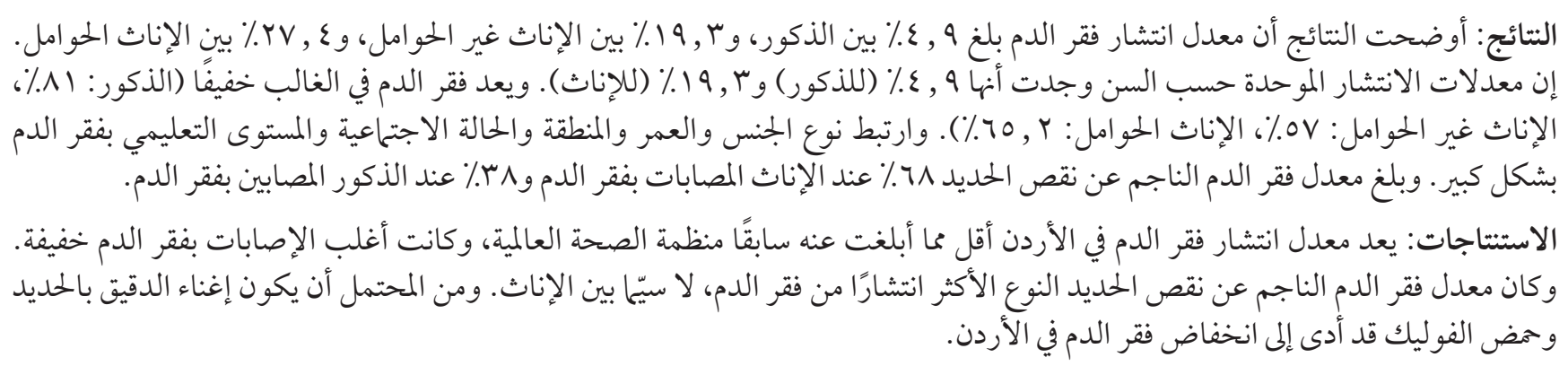

\section{References}

1. World Health Organization. Haemoglobin concentrations for the diagnosis of anaemia and assessment of severity. Geneva: World Health Organization; 2011. (http://www.who. int/vmnis/indicators/haemoglobin.pdf).

2. Culleton BF, Manns BJ, Zhang J, Tonelli M, Klarenbach S, Hemmelgarn BR. Impact of anemia on hospitalization and mortality in older adults. Blood. 2006 May 15;107(10):3841-6. http://dx.doi.org/10.1182/blood-2005-10-4308

3. World Health Organization. Report of a Joint World Health Organization/Centers for Disease Control and Prevention Technical Consultation on the assessment of iron status at the population level. Geneva: World Health Organization; 2007.

4. Carter RC, Jacobson JL, Burden MJ, Armony-Sivan R, Dodge NC, Angelilli ML, et al. Iron deficiency anemia and cognitive function in infancy. Pediatrics. 2010 Aug 1;126(2):e427-34. http://dx.doi.org/10.1542/peds.2009-2097

5. $\quad$ Killip S, Bennett JM, Chambers MD. Iron deficiency anemia. Am Fam Physician. 2007 Mar 1;75(5):671-8 PMID: 17375513

6. Saydam BK, Genc RE, Sarac F, Turfan EC. Prevalence of anemia and related factors among women in Turkey. Pak J Med Sci. 2017 Mar;33(2):433. 10.12669/pjms.332.11771

7. Anchang-Kimbi JK, Nkweti VN, Ntonifor HN, Apinjoh TO, Chi HF, Tata RB, et al. Profile of red blood cell morphologies and causes of anaemia among pregnant women at first clinic visit in the mount Cameroon area: a prospective cross sectional study. BMC Res Notes. 2017 Dec;10(1):645. http://dx.doi.org/10.1186/s13104-017-2961-6

8. Patel KV. Epidemiology of anemia in older adults. In Seminars in hematology 2008 Vol. 45, No. 4, pp. 210-217. WB Saunders. http://dx.doi.org/10.1053/j.seminhematol.2008.06.006

9. Jarrah SS, Halabi JO, Bond AE, Abegglen J. Iron deficiency anemia (IDA) perceptions and dietary iron intake among young women and pregnant women in Jordan. J Transcult Nurs. 2007 Jan;18(1):19-27. http://dx.doi.org/10.1177/1043659606294193

10. Mohammad A, Salahat I. Prevalence of anemia among Jordanian pregnant women and the effect of early pregnancy on alkaline phosphatase activity. Jordan Journal of Biological Sciences. 2012 Mar;5(1):65-70.

11. World Health Organization. Worldwide prevalence of anaemia 1993-2005. Geneva: World Health Organization; 2006.

12. WHO. The global prevalence of anaemia in 2011. Geneva: World Health Organization; 2015.

13. Le CH. The Prevalence of Anemia and Moderate-Severe Anemia in the US Population (NHANES 2003-2012). PLoS One. 2016 Nov 15;11(11):e0166635. http://dx.doi.org/10.1371/journal.pone.0166635

14. AlQuaiz AM, Gad Mohamed A, Khoja TA, AlSharif A, Shaikh SA, Al Mane H, Aldiris A, Kazi A, Hamad D. Prevalence of anemia and associated factors in child bearing age women in Riyadh, Saudi Arabia. Journal of nutrition and metabolism. 2013 Sep 24;2013. http://dx.doi.org/10.1155/2013/636585

15. Ismail IM, Kahkashan A, Antony A, Sobhith VK. Role of socio-demographic and cultural factors on anemia in a tribal population of North Kerala, India. International Journal Of Community Medicine And Public Health. 2017 Feb 3;3(5):1183-8. 10.18203/23946040.ijcmph20161381

16. Guralnik JM, Eisenstaedt RS, Ferrucci L, Klein HG, Woodman RC. Prevalence of anemia in persons 65 years and older in the United States: evidence for a high rate of unexplained anemia. Blood. 2004 Oct 15;104(8):2263-8. http://dx.doi.org/10.1182/ blood-2004-05-1812

17. Jaiswal M, Pandey S. Prevalence of anemia and its associated sociodemographic factors in apparently healthy individuals presenting as prospective blood donors at a Medical Institute of Rohilkhand region. International Journal of Medical Science and Public Health. 2017 Apr 1;6(4):792-8. http://dx.doi.org/10.5455/ijmsph.2017.1267918122016

18. Mugisha JO, Baisley K, Asiki G, Seeley J, Kuper H. Prevalence, types, risk factors and clinical correlates of anaemia in older people in a rural Ugandan population. PLoS One. 2013 Oct 23;8(10):e78394. http://dx.doi.org/10.1371/journal.pone.0078394

19. Leenstra T, Kariuki SK, Kurtis JD, Oloo AJ, Kager PA, ter Kuile FO. Prevalence and severity of anemia and iron deficiency: cross-sectional studies in adolescent schoolgirls in western Kenya. Eur J Clin Nutr. 2004 Apr 1;58(4):681-91. http://dx.doi. org/10.1038/sj.ejcn.1601865

20. Zaytoun SS, Khan EA. Sociodemograaphic risk factors of iron deficiency anemia in young adults males of upper Egypt. Khyber Medical University Journal. 2016 Jul 1;8(3). 
21. Sharma P, Mehta S, Nagar R. Prevalence of anemia and socio-demographic factors associated with anemia among pregnant women attending antenatal Hospital in Jaipur City, India. Age (Omaha). 2013;20:20-5.

22. Choi HJ, Lee HJ, Jang HB, Park JY, Kang JH, Park KH, et al. Effects of maternal education on diet, anemia, and iron deficiency in Korean school-aged children. BMC Public Health. 2011 Dec 1;11(1):870. http://dx.doi.org/10.1186/1471-2458-11-870

23. Al-Sweedan SA, Alhaj M. The effect of low altitude on blood count parameters. Hematol Oncol Stem Cell Ther. 2012;5(3):158-61. http://dx.doi.org/10.5144/1658-3876.2012.158

24. Nordenberg D, Yip R, Binkin NJ. The effect of cigarette smoking on hemoglobin levels and anemia screening. JAMA. 1990 Sep 26;264(12):1556-9. http://dx.doi.org/10.1001/jama.1990.03450120068031 